\title{
KUALITAS DIET, AKTIVITAS FISIK, DAN STATUS GIZI PADA PEROKOK DEWASA AWAL
}

\author{
Fidi Restutiwati. Etisa Adi Murbawani*. Ayu Rahadiyanti \\ Departemen Ilmu Gizi, Fakultas Kedokteran, Universitas Diponegoro \\ J1. Prof. Sudarto SH, Tembalang, Semarang, Jawa Tengah 50275, Indonesia \\ *Penulis Penanggungjawab. E-mail: etisatitis@gmail.com
}

\begin{abstract}
Background: Smoking habit had impact on diet quality, physical activity, and nutritional status. Cigarettes contained nicotine which could decrease appetite and decrease cardiorespiratory ability which interfered physical activity. This study aimed to determine differences in diet quality and physical activity according nutritional status in early adult smokers.

Method: The design of this study was cross sectional with 59 subjects aged 20-24 years. Data included subject characteristics, diet quality was obtained by the Semi Quantitative-Food Frequency Questionniare (SQ-FFQ) method, physical activity obtained by the International Physical Activity Questionnaire-Short Form (IPAQ-SF) method, and nutritional status was measured using waist circumference and/or Waist Hip Ratio (WHR). Data analysis used chi-square test and fisher exact.

Results: The diet quality score mean of subject was 40.4 \pm 8.7 , classified as low diet. The low diet quality in the subject as consequence low intake of vegetables and fruits, high intake of total fat, saturated fat, cholesterol, sodium, low score of the macronutrient ratio and the ratio of fatty acids. The physical activity mean of and subject as $2569.5 \pm 1806.5$ METs/min/ week classified as moderate physical activity. Difference test was resulted diet quality based on nutritional status ( $p=0.564)$, physical activity based on nutritional status $(p=0.019)$.

Conclusion: There was no significant difference in diet quality based on nutritional status in early adult smokers ( $p>0.05)$. There was significant difference in physical activity based on nutritional status in early adult smokers $(p<0.05)$.
\end{abstract}

Keywords: diet quality; physical activity; nutritional status; adults; smokers

\section{ABSTRAK}

Latar Belakang: Kebiasaan merokok berdampak pada kualitas diet, aktivitas fisik dan status gizi. Rokok mengandung nikotin yang dapat menurunkan nafsu makan dan mengakibatkan penurunan kemampuan kardiorespirasi sehingga mengganggu aktivitas fisik seseorang. Penelitian ini bertujuan untuk mengetahui perbedaan kualitas diet dan aktivitas fisik menurut status gizi pada perokok dewasa awal.

Metode: Rancangan penelitian ini adalah cross sectional dengan jumlah sampel 59 subjek yang berusia 20-24 tahun. Data meliputi karakteristik subjek, kualitas diet diperoleh dengan metode Semi Quantitative-Food Frequency Questionniare (SQ-FFQ), aktivitas fisik diperoleh dengan metode International Physical Activity Questionnaire-Short Form (IPAQ-SF), dan status gizi diukur menggunakan lingkar pinggang dan/atau Rasio Lingkar Pinggang Panggul (RLPP). Analisis data dengan uji chi-square, fisher exact.

Hasil: Rerata skor kualitas diet subjek yaitu 40,4 $\pm 8,7$ tergolong kualitas diet rendah. Kualitas diet rendah pada subjek digambarkan dengan rendahnya asupan sayur dan buah, tingginya asupan total lemak, lemak jenuh, kolesterol, natrium, rendahnya skor rasio makronutrien dan rasio asam lemak. Rerata aktivitas fisik subjek yaitu 2569,5 $\pm 1806,5$ METs/min/minggu termasuk dalam aktivitas fisik sedang. Hasil uji perbedaan diperoleh kualitas diet menurut status gizi ( $p=0,564)$, aktivitas fisik menurut status gizi $(p=0,019)$.

Simpulan: Tidak ada perbedaan signifikan kualitas diet menurut status gizi pada perokok dewasa awal (p>0,05). Ada perbedaan signifikan aktivitas fisik menurut status gizi pada perokok dewasa awal $(p<0,05)$.

Kata Kunci: kualitas diet; aktivitas fisik; status gizi; dewasa; perokok

\section{PENDAHULUAN}

Masa dewasa awal merupakan kelompok usia yang memiliki pola kegiatan yang tergolong tinggi seperti jadwal perkuliahan dan kegiatan eksternal yang padat, waktu kerja yang ketat, dan waktu di rumah yang singkat. Pola kegiatan tersebut dapat mengganggu perilaku konsumsi pangan bergizi seimbang karena peningkatan risiko terpapar polusi, makanan tidak aman, dan ketersediaan berbagai makanan siap saji dan siap olah yang dapat menyebabkan aktivitas sedenter. ${ }^{1}$

Menurut World Health Organization (WHO), Indonesia merupakan negara ketiga dengan jumlah perokok terbesar di dunia setelah Cina dan India. ${ }^{2}$ Data Global Youth Tobacco Survey (GYTS 2014) menunjukkan bahwa kebiasaan merokok pada 
usia dewasa awal di Indonesia sebesar 26,7\% sedangkan di wilayah Semarang prevalensi perokok sebesar 34,2\% dengan jumlah rokok yang dihisap sebanyak 8,2 batang perhari. ${ }^{3,4}$

Kebiasaan merokok berdampak pada kualitas diet. Perubahan pola makan terkait merokok disebabkan nikotin yang menekan nafsu makan dan menurunkan persepsi terhadap rasa dan bau sehingga menyebabkan perokok kurang tertarik untuk mengonsumsi buah dan sayur. ${ }^{5}$ Saat merokok, terjadi absorbsi nikotin secara cepat yang berasal dari tembakau ke dalam paru-paru dan masuk ke dalam otak. Nafsu makan juga dipengaruhi oleh beberapa hormon akibat pengaruh dari nikotin antara lain dopamine, norephinefrin, dan leptin. ${ }^{6}$ Neuropeptida $\mathrm{Y}$ adalah peptida yang dapat meningkatkan asupan makan dan terletak di nukleus arkuata hipotalamus. Akan tetapi, nikotin yang terkandung pada rokok, dapat menekan peptida tersebut sehingga terjadi penurunan nafsu makan. ${ }^{5}$

Berdasarkan penelitian di Iran, pola hidup non perokok lebih banyak mengonsumsi buah dan sayuran, sedangkan perokok mengkonsumsi lebih banyak daging dan makanan berlemak. Hal ini dapat disimpulkan bahwa perokok berat memiliki kualitas diet rendah dan berhubungan dengan asupan rendah antioksidan. ${ }^{7}$ Penelitian di Kanada melaporkan bahwa asupan lemak total dan lemak jenuh pada perokok tergolong lebih tinggi, sedangkan asupan asam folat, vitamin $\mathrm{C}$, dan serat pada perokok tergolong lebih rendah dibandingkan non perokok. ${ }^{8}$ Sementara, hasil penelitian di Pakistan menunjukkan asupan energi, karbohidrat, vitamin A, dan seng pada perokok lebih tinggi dibanding non perokok serta asupan protein dan lemak perokok lebih rendah daripada non perokok. ${ }^{9}$

Merokok dapat berdampak pada aktivitas fisik seseorang yang diakibatkan oleh karbon monoksida yang dapat menimbulkan terjadinya penurunan kemampuan kardiorespirasi. Penelitian di Yunani menunjukkan laki-laki perokok dengan aktivitas fisik rendah sebesar 52,7\%, aktivitas fisik sedang sebesar $37,4 \%$, dan aktivitas fisik berat sebesar 10,3\%. ${ }^{10}$ Berdasarkan penelitian di Finlandia menunjukkan sebanyak $15,9 \%$ perokok memiliki aktivitas fisik berat dan 44,9\% perokok memiliki aktivitas fisik ringan. ${ }^{11}$

Kualitas diet dan aktivitas fisik berdampak pada status gizi. Indikator status gizi yang dapat digunakan untuk mengukur obesitas sentral antara lain lingkar pinggang dan rasio lingkar pinggang panggul (RLPP). Lingkar pinggang dan RLPP memiliki korelasi positif dengan obesitas sentral. ${ }^{12}$ Obesitas sentral merupakan kondisi kelebihan lemak abdominal yang berhubungan dengan risiko kesehatan dibanding status obesitas. ${ }^{13}$ Riskesdas
2018 menunjukkan prevalensi obesitas sentral meningkat menjadi $31 \% .^{14}$ Lingkar pinggang memiliki sensitifitas $83,6 \%$ dan spesifisitas $82,5 \%$, sedangkan RLPP yang memiliki sensitifitas $70 \%$ dan spesifisitas $64,1 \%$, sehingga lingkar pinggang dan RLPP merupakan indikator status gizi yang sensitif untuk menilai obesitas sentral. ${ }^{15,16}$ Lingkar pinggang merupakan salah satu indikator yang lebih sensitif dalam menilai distribusi lemak di tubuh terutama yang berada di dinding abdomen. ${ }^{17}$ Hasil penelitian di Jakarta menunjukkan status gizi mahasiswa perokok dan non perokok yang tergolong normal sebesar 49,1\%, sedangkan penelitian di India menunjukkan perokok aktif yang memiliki status gizi underweight sebesar 36,1\%.6,18 Sebaliknya hasil penelitian di Arab Saudi menunjukkan status gizi perokok yang tergolong overweight dan obesitas sebesar $61,7 \%{ }^{19}$

Berdasarkan pemaparan di atas, terdapat perokok yang memiliki asupan zat gizi tinggi dan rendah, aktivitas fisik rendah, sedang, dan berat, serta status gizi yang tergolong underweight, overweight, dan obesitas, sehingga masih terdapat pro dan kontra terkait kualitas diet, aktivitas fisik, dan status gizi pada perokok. Oleh karena itu, perlu dilakukan penelitian mengenai perbedaan kualitas diet dan aktivitas fisik menurut status gizi perokok dewasa awal.

\section{METODE}

Penelitian ini dilaksanakan di Universitas Diponegoro pada Maret - April 2019. Penelitian ini termasuk lingkup gizi masyarakat dan merupakan studi observasional dengan desain cross sectional. Populasi pada penelitian ini yaitu laki-laki perokok dewasa awal usia 20-24 tahun. Pengambilan subjek diawali dengan melakukan skrining pada perokok dewasa awal untuk mengkategorikan sebagai perokok aktif. Selanjutnya, subjek diambil dengan cara cluster random sampling untuk mendapatkan 59 subjek. Penelitian ini telah mendapat surat izin etik No.78/EC/FK UNDIP/III/2019.

Data yang dikumpulkan dalam penelitian ini yaitu identitas subjek, kualitas diet, aktivitas fisik, dan status gizi. Variabel bebas dalam penelitian ini yaitu kualitas diet dan aktivitas fisik. Kualitas diet adalah penilaian konsumsi makanan yang terdiri dari 4 kategori utama yaitu variasi, kecukupan, moderasi, dan keseimbangan keseluruhan berdasarkan Angka Kecukupan Gizi (AKG) dan Pedoman Umum Gizi Seimbang (PUGS) dengan menggunakan formulir DQI-I (Diet Quality Index International). Total nilai dalam DQI-I mulai dari 0 sampai 100 (0 adalah skor terendah dan 100 adalah skor tertinggi). Kualitas diet dinilai rendah jika skor $\leq 60$ dan kualitas diet dinilai tinggi jika skor $>60 .{ }^{20-22}$ Asupan makan diperoleh 
menggunakan Semi Quantitative-Food Frequency Questionniare $(S Q-F F Q)$. Perhitungan konsumsi natrium menggunakan pedoman perkiraan jumlah garam. ${ }^{23}$ Pengukuran aktivitas fisik menggunakan International Physical Activity Questionnaire-Short Form (IPAQ-SF). Aktivitas fisik digolongkan kedalam 2 kategori, yaitu kategori sedang dan berat. Aktivitas fisik tergolong berat jika memiliki aktivitas dengan intensitas tinggi setidaknya 7 hari mencapai total aktivitas fisik $\geq 3000 \mathrm{MET} / \mathrm{min} / \mathrm{minggu}$. Aktivitas fisik tergolong sedang jika subjek memiliki aktivitas fisik $<3000 \mathrm{MET} / \mathrm{min} / \mathrm{minggu} .^{24,25}$ Variabel terikat dalam penelitian ini yaitu status gizi diukur dengan menggunakan lingkar pinggang dan/atau rasio lingkar pinggang panggul (RLPP). Lingkar pinggang dan lingkar panggul diukur menggunakan pita ukur medline. Lingkar pinggang diukur pada titik tengah antara tulang rusuk bawah dan crista iliaca, sedangkan lingkar panggul diukur pada bagian atas symphysis pubis dan bagian maksimum dari regio gluteus. Pengukuran lingkar pinggang dan lingkar panggul dilakukan sebanyak 2x. Cut off point lingkar pinggang untuk laki-laki Asia yaitu $<90 \mathrm{~cm}$ dan RLPP yaitu $<0,95 .{ }^{26}$ Subjek tergolong obesitas sentral jika memiliki lingkar pinggang $\geq 90 \mathrm{~cm}$ dan/ atau RLPP $\geq 0,95$.

Analisis univariat dilakukan untuk mendeskripsikan setiap variabel yaitu kualitas diet, aktivitas fisik, lingkar pinggang, dan RLPP subjek penelitian. Analisis bivariat digunakan untuk mengetahui perbedaan kualitas diet dan aktivitas fisik menurut status gizi pada perokok dewasa awal. Analisis bivariat menggunakan uji chi square dan fisher exact.

\section{HASIL}

Subjek merupakan perokok dewasa awal di Universitas Diponegoro. Seluruh subjek berjenis kelamin laki-laki sebanyak 59 subjek dari 4 fakultas yang berbeda.

Tabel 1. Karakteristik Subjek Berdasarkan Usia dan Antropometri

\begin{tabular}{|c|c|c|c|c|c|}
\hline Variabel & Rerata \pm SD & Min & Max & $\mathbf{n}$ & $\%$ \\
\hline Usia (tahun) & $21,5 \pm 0,9$ & 20 & 23,75 & & \\
\hline $\operatorname{IMT}^{*}\left(\mathrm{~kg} / \mathrm{m}^{2}\right)^{27}$ & $23,2 \pm 5,9$ & 12,09 & 41,66 & & \\
\hline Sangat Kurus $<17,0$ & & & & 5 & 8,5 \\
\hline Kurus $\geq 17,0-<18,5$ & & & & 6 & 10,2 \\
\hline Normal $\geq 18,5-<24,9$ & & & & 29 & 49,1 \\
\hline Gemuk $\geq 25,0-<27,0$ & & & & 3 & 5,1 \\
\hline Obesitas $\geq 27,0$ & & & & 16 & 27,1 \\
\hline Lingkar Pinggang $^{26}$ & $79,7 \pm 13,9$ & 59,2 & 122 & & \\
\hline Obesitas Sentral $(\geq 90 \mathrm{~cm})$ & & & & 13 & 22 \\
\hline Non Obesitas Sentral $(<90 \mathrm{~cm})$ & & & & 46 & 78 \\
\hline RLPP $* 26$ & $0,82 \pm 0,06$ & 0,73 & 0,98 & & \\
\hline Obesitas Sentral $(\geq 0,95)$ & & & & 2 & 3,4 \\
\hline Non Obesitas Sentral $(<0,95)$ & & & & 57 & 96,6 \\
\hline
\end{tabular}

Tabel 2. Karakteristik Subjek Berdasarkan Konsumsi Rokok dan Alasan Merokok

\begin{tabular}{|c|c|c|c|c|c|}
\hline Variabel & Rerata \pm SD & Min & Max & $\mathrm{n}$ & $\%$ \\
\hline Lama Merokok (tahun) & $4,5 \pm 2,8$ & 0,5 & 13 & & \\
\hline 1-2 tahun & & & & 20 & 33,9 \\
\hline $3-5$ tahun & & & & 15 & 25,4 \\
\hline$>5$ tahun & & & & 24 & 40,7 \\
\hline Frekuensi merokok (batang/hari) & $8,7 \pm 4,8$ & 2 & 20 & & \\
\hline 1-10 batang/hari & & & & 40 & 67,8 \\
\hline 11-20 batang/hari & & & & 19 & 32,2 \\
\hline \multicolumn{6}{|l|}{ Alasan Merokok } \\
\hline Pengaruh lingkungan & & & & 36 & 61 \\
\hline Menurunkan tingkat stres & & & & 14 & 23,7 \\
\hline Kebutuhan & & & & 9 & 15,3 \\
\hline
\end{tabular}

Tabel 1 menunjukkan usia subjek berkisar antara 20 hingga 23,75 tahun dengan rata-rata usia 21,5 $\pm 0,9$ tahun. Separuh subjek penelitian ini $(50,9 \%)$ tergolong malnutrisi (gizi kurang dan gizi lebih). Berdasarkan penilaian lingkar pinggang, sebagian besar subjek (78\%) memiliki status gizi non obesitas sentral. Berdasarkan penilaian RLPP, $(96,6 \%)$ hampir semua subjek termasuk dalam kategori non obesitas sentral.

Berdasarkan hasil penelitian ini diperoleh hasil yang menunjukkan sebagian besar subjek $(40,7 \%)$ sudah merokok lebih dari 5 tahun. Sebagian 
besar subjek $(67,8 \%)$ mengkonsumsi rokok sebanyak 1-10 batang/hari dan tergolong ke dalam perokok ringan. Pengaruh lingkungan seperti pengaruh dari teman, keluarga, iklan, untuk mempermudah bersosialisasi, dan ingin terlihat keren merupakan alasan sebagian besar subjek (61\%) untuk merokok.
Kualitas diet dinilai dengan menggunakan DQI-I yang telah disesuaikan dengan kondisi penelitian, setiap komponen yang digunakan berdasarkan Angka Kecukupan Gizi (AKG) dan Pedoman Umum Gizi Seimbang (PUGS).

Tabel 3. Gambaran Kategori Kualitas Diet

\begin{tabular}{|c|c|c|c|c|}
\hline Komponen Kualitas Diet & Rerata \pm SD & Min & Max & Tingkat Skor \\
\hline Variasi (skor) & $14 \pm 3,8$ & 7 & 20 & $0-20$ \\
\hline Semua kelompok makanan (poin) & $10,6 \pm 2,5$ & 6 & 15 & $0-15$ \\
\hline Sumber Protein (poin) & $3,4 \pm 1,6$ & 1 & 5 & $0-5$ \\
\hline Kecukupan (skor) & $18,2 \pm 5,2$ & 10 & 36 & $0-40$ \\
\hline Kelompok sayuran (poin) & $0,2 \pm 1,0$ & 0 & 5 & $0-5$ \\
\hline Kelompok buah (poin) & $0,7 \pm 1,7$ & 0 & 5 & $0-5$ \\
\hline Kelompok padi-padian (poin) & $4,3 \pm 1,0$ & 1 & 5 & $0-5$ \\
\hline Serat (poin) & $1,2 \pm 0,6$ & 1 & 3 & $0-5$ \\
\hline Protein (poin) & $4,6 \pm 0,7$ & 3 & 5 & $0-5$ \\
\hline Besi (poin) & $2,9 \pm 1,5$ & 1 & 5 & $0-5$ \\
\hline Kalsium (poin) & $1,5 \pm 1,0$ & 1 & 5 & $0-5$ \\
\hline Vitamin C (poin) & $2,4 \pm 1,7$ & 1 & 5 & $0-5$ \\
\hline Moderasi (skor) & $12,4 \pm 5,2$ & 3 & 27 & $0-30$ \\
\hline Total lemak (poin) & $0,8 \pm 1,8$ & 0 & 6 & $0-6$ \\
\hline Lemak jenuh (poin) & $1,8 \pm 2,0$ & 0 & 6 & $0-6$ \\
\hline Kolesterol (poin) & $2,1 \pm 2,6$ & 0 & 6 & $0-6$ \\
\hline Natrium (poin) & $1,6 \pm 1,9$ & 0 & 6 & $0-6$ \\
\hline Makanan dan minuman rendah zat gizi (poin) & $0,7 \pm 1,3$ & 0 & 3 & $0-6$ \\
\hline Keseimbangan Keseluruhan (skor) & $0,67 \pm 1,46$ & 0 & 6 & $0-10$ \\
\hline Rasio makronutrien (poin) & $0,6 \pm 1,4$ & 0 & 6 & $0-6$ \\
\hline Rasio asam lemak (poin) & $0,03 \pm 0,2$ & 0 & 2 & $0-4$ \\
\hline Total Kualitas Diet & $40,4 \pm 8,7$ & 26 & 66 & $0-100$ \\
\hline
\end{tabular}

Kategori variasi digunakan untuk menilai asupan berasal dari sumber yang berbeda. Hasil penelitian ini menunjukkan makanan yang dikonsumsi subjek sudah cukup bervariasi dengan

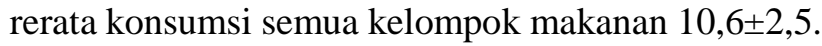

Kategori kecukupan mengevaluasi zat gizi dari asupan makanan yang seharusnya tersedia dalam jumlah yang cukup. Secara keseluruhan, asupan kelompok sayuran dan buah pada subjek tergolong rendah. Sementara konsumsi padi-padian dan protein subjek tergolong tinggi. Konsumsi paling rendah pada kategori ini yaitu kelompok sayuran dengan rerata $0,2 \pm 1,0$.

Kategori moderasi mengevaluasi asupan makanan dan zat gizi yang perlu dibatasi. Hasil penelitian ini menunjukkan konsumsi kategori moderasi tergolong berlebih sehingga sebagian besar subjek mendapat skor rendah. Selain itu, sebagian besar komponen dalam kategori moderasi berperan dalam rendahnya kualitas diet pada subjek. Rerata terendah pada kategori moderasi yaitu makanan dan minuman rendah zat gizi sebesar $0,7 \pm 1,3$ yang menunjukkan konsumsi makanan dan minuman rendah zat gizi pada subjek tergolong tinggi.
Kategori keseimbangan keseluruhan merupakan kategori yang menganalisis keseimbangan keseluruhan diet dalam hal proporsionalitas antara sumber-sumber energi dan komposisi asam lemak. Rerata kategori keseimbangan keseluruhan pada subjek tergolong rendah yaitu $0,67 \pm 1,46$. Komponen rasio asam lemak menunjukkan sebagian besar subjek memiliki asupan Saturated Fatty Acids (SFAs) yang lebih tinggi dibanding asupan Polyunsaturated Fatty Acids (PUFAs) dan Monounsaturated Fatty Acids (MUFAs).

Aktivitas fisik subjek dibagi menjadi 2 kategori yaitu sedang dan berat. Sebaran subjek berdasarkan aktivitas fisik dalam 7 hari terakhir. Lebih dari separuh subjek memiliki aktivitas fisik sedang $(62,7 \%)$. Rerata aktivitas fisik subjek yaitu 2569,5 $\pm 1806,5$ METs/min/minggu. Hal ini diakibatkan dari jenis kegiatan yang dilakukan subjek tergolong kedalam aktivitas fisik sedang. Aktivitas fisik sedang berarti subjek memiliki gerakan tubuh yang dilakukan sangat minimal baik dari jenisnya maupun frekuensinya. 
Tabel 4. Analisis Perbedaan Kualitas Diet dan Aktivitas Fisik Menurut Status Gizi

\begin{tabular}{|c|c|c|c|c|c|}
\hline \multirow{3}{*}{ Variabel } & \multicolumn{4}{|c|}{ Status Gizi } & \multirow{3}{*}{$\mathbf{P}$} \\
\hline & \multicolumn{2}{|c|}{ Obesitas Sentral $(n=14)$} & \multicolumn{2}{|c|}{ Non Obesitas Sentral $(n=45)$} & \\
\hline & $\mathbf{n}$ & $\%$ & $\mathbf{n}$ & $\%$ & \\
\hline \multicolumn{6}{|l|}{ Kualitas Diet } \\
\hline Rendah & 13 & 23,2 & 43 & 76,8 & \multirow{2}{*}{$0,564 *$} \\
\hline Tinggi & 1 & 33,3 & 2 & 66,7 & \\
\hline \multicolumn{6}{|c|}{ Aktivitas Fisik } \\
\hline Sedang & 13 & 35,1 & 24 & 64,9 & \multirow{2}{*}{$0,019 * *$} \\
\hline Berat & 1 & 4,5 & 21 & 95,5 & \\
\hline
\end{tabular}

Sebagian besar subjek non obesitas sentral (76,8\%) memiliki kualitas diet rendah. Sebanyak 64,9\% subjek non obesitas sentral memiliki aktivitas fisik sedang. Hasil uji perbedaan antara variabel kualitas diet dan status gizi diperoleh $(\mathrm{p}=0,564)$ maka dapat disimpulkan bahwa tidak ada perbedaan signifikan kualitas diet menurut status gizi pada perokok dewasa awal, sedangkan hasil uji perbedaan antara variabel aktivitas fisik dan status gizi diperoleh $(\mathrm{p}=0,019)$ maka dapat disimpulkan bahwa ada perbedaan signifikan aktivitas fisik menurut status gizi pada perokok dewasa awal.

\section{PEMBAHASAN}

Subjek pada penelitian ini yaitu perokok dewasa awal dengan jumlah sampel sebanyak 59 orang. Subjek pada penelitian ini tidak semuanya berasal dari daerah Semarang, tetapi dari berbagai daerah di Indonesia yang memiliki kebiasaan makan dan aktivitas fisik yang berbeda.

Usia subjek dalam penelitian ini berkisar antara 20-24 tahun. Berdasarkan pengukuran IMT sebagian besar subjek $(50,9 \%)$ tergolong malnutrisi (gizi kurang dan gizi lebih). Hasil tersebut sejalan dengan penelitian di Indonesia yang menunjukkan sebanyak $43,63 \%$ perokok tergolong malnutrisi. ${ }^{6}$ Lingkar pinggang dan RLPP adalah indikator yang berhubungan dengan jumlah jaringan adiposa visceral. ${ }^{28}$ Lingkar pinggang memiliki korelasi yang lebih kuat dengan distribusi lemak pada abdomen dibanding dengan IMT. RLPP baik digunakan untuk pengukuran obesitas sentral karena menggunakan perbandingan antara lingkar pinggang dan lingkar panggul. ${ }^{26}$ Penelitian di Amerika menunjukkan bahwa lingkar pinggang sangat berhubungan dengan jaringan adiposa tubuh yang berarti bahwa lingkar pinggang merupakan indikator yang baik digunakan untuk pengukuran obesitas sentral. ${ }^{12}$ Berdasarkan penilaian lingkar pinggang, sebanyak $78 \%$ subjek tergolong non obesitas sentral. Hasil penelitian ini sejalan dengan penelitian di Pakistan yang menunjukkan perokok memiliki lngkar pinggang lebih rendah yang dihubungkan dengan meningkatnya pengeluaran energi dan aktivitas fisik sehingga mengakibatkan rendahnya adipositas pada perokok. ${ }^{9}$ Hasil pengukuran lingkar pinggang sejalan dengan hasil peneltian di Iran yang menunjukkan rata-rata lingkar pinggang perokok yaitu $87,94 \pm 9,9$ $\mathrm{cm}$ yang tergolong non obestas sentral. ${ }^{7}$ Berdasarkan penilaian RLPP, sebanyak 96,6\% subjek termasuk dalam kategori non obesitas sentral. Hasil pengukuran RLPP sejalan dengan hasil penelitian di Pakistan yang menunjukkan RLPP subjek perokok dengan rata-rata $0,89 \pm 0,06$ yang tergolong non obesitas sentral. ${ }^{9}$

Sebagian besar subjek $(59,3 \%)$ sudah merokok selama 1-5 tahun. Setiap hari subjek merokok dengan rata-rata jumlah rokok yang dikonsumsi sebanyak $8,7 \pm 4,8$ batang/hari, sehingga dapat digolongkan dalam perokok ringan yaitu 1-10 batang rokok/hari. ${ }^{29}$ Jenis rokok yang banyak dikonsumsi oleh subjek yaitu rokok filter dan kretek. Pengaruh lingkungan seperti pengaruh dari teman, keluarga, iklan, untuk mempermudah bersosialisasi, dan ingin terlihat keren merupakan alasan sebagian besar subjek (61\%) untuk merokok. Selain itu, alasan lain subjek untuk merokok yaitu untuk menurunkan tingkat stress yang dialami subjek.

Kualitas diet terdiri dari empat kategori utama, yaitu variasi, kecukupan, moderasi, dan keseimbangan keseluruhan. Hasil analisis berdasarkan pemenuhan zat gizinya, beberapa komponen pada kategori kecukupan, moderasi dan keseimbangan keseluruhan yang memiliki poin rendah membuat skor kualitas diet pada subjek tergolong rendah. Kualitas diet yang rendah disebabkan oleh kurangnya beberapa zat gizi di kategori kecukupan, berlebihnya beberapa zat gizi pada kategori moderasi, dan rendahnya keseimbangan keseluruhan (rasio makronutrien dan asam lemak). Sebagian besar subjek hanya memenuhi asupan kelompok padi-padian dan protein, sedangkan kelompok sayur, buah, serat, besi, kalsium, dan vitamin $\mathrm{C}$ pada subjek sebagian besar kurang dari kebutuhan. Asupan serat dan vitamin $\mathrm{C}$ yang rendah disebabkan rendahnya konsumsi kelompok makanan yang mengandung serat dan vitamin $\mathrm{C}$ tinggi, seperti sayuran dan buah-buahan. Sejalan dengan penelitian 
di Pakistan yang menunjukkan perokok lebih jarang mengkonsumsi sayur dan buah sehingga mengakibatkan terjadinya kekurangan zat gizi mikro dan pola diet yang tidak seimbang. ${ }^{9}$

Dilihat dari skor komponen DQI-I, subjek lebih banyak mengkonsumsi makanan berlemak dan mengandung tinggi natrium serta rendah konsumsi sayur dan buah. Hasil penelitian dari data SQ-FFQ menunjukkan sumber makanan yang sering dikonsumsi subjek yaitu berupa one dish meal yang terdiri dari sumber karbohidrat, protein, lemak, dan sedikit sayuran seperti kwetiau, mie bakso, mie ayam, lontong sayur, lontong sate, siomay, dan bubur ayam. Rata-rata subjek mengkonsumsi nasi $>2 \mathrm{x} /$ hari dengan porsi 1,5-6 porsi per hari. Sumber protein yang banyak dikonsumsi yaitu tahu, tempe, unggas, ikan, seafood, dan telur. Rata-rata kecukupan protein subjek yaitu $8-15 \%$ dari total energi/hari dan besar porsi yang dikonsumsi yaitu 3-5 porsi/hari. Sayursayuran yang banyak dikonsumsi yaitu lalapan, sedangkan masakan yang diolah dengan cara ditumis maupun kuah jarang dikonsumsi oleh subjek walaupun terdapat beberapa subjek yang mengkonsumsi sayur dengan olahan tersebut. Sebagian besar subjek mengkonsumsi sayuran dalam porsi kecil yaitu kurang dari setengah maupun satu porsi. Rata-rata asupan sayur subjek sebanyak 2-4 sendok makan atau 1-2 sendok sayur dan sebagian subjek tidak mengkonsumsi sayur setiap hari. Subjek tidak mengkonsumsi buah-buahan setiap hari, ratarata konsumsi buah subjek sebanyak 2-3x/minggu. Porsi buah yang dikonsumsi hanya beberapa potong karena lebih banyak mengkonsusmi dalam jenis rujak buah. Terdapat beberapa subjek yang mengkonsumsi buah setiap hari dan lebih dari 2 porsi. Akan tetapi terdapat subjek yang tidak mengkonsumi buahbuahan dalam satu bulan terakhir. Konsumsi sayur dan buah yang rendah pada perokok terjadi karena adanya perubahan ketajaman rasa sehingga mendorong perokok untuk memilih makanan. ${ }^{8}$ Produk susu dan olahannya yang banyak dikonsumsi yaitu susu full cream cair atau susu kemasan. Kental manis merupakan subkategori susu kental yang sering dikonsumsi subjek kurang lebih 1-3x/minggu sebanyak 1 sachet per hari. Sebagian besar subjek mengkonsumsi kopi dan teh setiap hari sebanyak $>2 \mathrm{x} /$ hari dengan penambahan gula pasir kurang lebih sebanyak 1-2 sendok makan setiap kali pembuatan kopi maupun teh, namun terdapat subjek yang mengkonsumsi kopi instan. Jajanan yang banyak dikonsumsi yaitu martabak manis, batagor, siomay, roti bakar, dan donat. Jajanan tersebut berbahan dasar tepung sehingga tergolong jajanan tinggi kalori dan rendah zat gizi.

Berdasarkan uji fisher exact diperoleh hasil perbedaan kualitas diet menurut status gizi $p=0,564$ maka tidak ada perbedaan kualitas diet menurut status gizi pada perokok dewasa awal $(p>0,05)$. Kualitas diet yang berhubungan dengan status gizi digambarkan dari hasil penilaian empat kategori kualitas diet. Perokok dewasa awal dengan status gizi non obesitas sentral maupun obesitas sentral memiliki variasi asupan sumber makanan yang tinggi. Pada kategori kecukupan, subjek memiliki asupan sayur, buah, serat, kalsium, besi, dan vitamin $\mathrm{C}$ yang rendah, sementara asupan makanan pokok dan protein tergolong tinggi. Akan tetapi pada kelompok non obesitas sentral memiliki memiliki asupan sayur yang lebih banyak dibanding obesitas sentral. Rerata kecukupan zat besi pada kedua kelompok tergolong tinggi, karena pada kedua kelompok tersebut lebih banyak mengkonsumsi sumber protein hewani. Pada kategori moderasi, subjek memiliki asupan total lemak, lemak jenuh, kolesterol, natrium, dan makanan rendah kalori yang tergolong tinggi sehingga memiliki skor yang rendah. Kelompok non obesitas sentral memiliki asupan natrium, kolesterol, total lemak, dan lemak jenuh yang lebih sedikit dibanding kelompok obesitas sentral. Kategori keseimbangan keseluruhan, subjek memiliki rasio makronutrien dan rasio asam lemak yang rendah. Merokok dapat meningkatkan asupan saturated fatty acids dan menurunkan konsumsi polyunsaturated fatty acids, besi, $\beta$-carotene dan vitamin $\mathrm{E}^{8}$ Penelitian ini sejalan dengan penelitian di Iran yang menunjukkan $67,7 \% \%$ perokok mengkonsumsi mentega setiap minggunya, sebanyak $45,5 \%$ mengkonumsi susu tinggi lemak, serta hanya $1,7 \%$ perokok mengkonsumsi sayur setiap hari. ${ }^{7}$ Sejalan dengan penelitian di Kanada yang menunjukkan asupan lemak total dan lemak jenuh pada perokok tergolong tinggi, sementara asupan vitamin $\mathrm{C}$ dan serat perokok tergolong rendah yang diakibatkan dari konsumsi sayur dan buah yang rendah. ${ }^{8}$ Efek merokok dapat menyebabkan ketergantungan yang dapat mengakibatkan terjadinya penurunan nafsu makan dan meningkatkan laju metabolisme sehingga terjadi penurunan berat badan dan berpengaruh terhadap status gizi. ${ }^{6}$ Nikotin bekerja pada reseptor nikotinik di otak dan ganglia otonom. Ikatan nikotin dengan reseptor nikotinik membuka saluran ion dan memungkinkan masuknya natrium dan kalsium sehingga menambah pelepasan berbagai neurotransmitter. Proses ini melepaskan katekolamin sistemik dan dalam sistem saraf pusat terjadi pelepasan dopamine, noreprinefrin, serotonin, asetilkolin, glutamat, asam $\gamma$ aminobutirat dan neurotransmiter lainnya. Pelepasan tersebut dapat menurunkan nafsu makan dan mengakibatkan penurunan berat badan. ${ }^{30}$

Sebagian besar subjek $(62,7 \%)$ memiliki aktivitas fisik sedang. Hasil penelitian ini sejalan 
dengan hasil penelitian di Yunani yang menunjukkan sebagian besar $(90,1 \%)$ perokok memiliki aktivitas fisik sedang. ${ }^{10}$ Selain itu, penelitian di Iran juga menujukkan $(71,7 \%)$ perokok memiliki aktivitas yang lebih ringan dibanding non perokok dan dengan rerata durasi aktivitas fisik 70,71 $\pm 16,4$ menit. ${ }^{7}$ Durasi aktivitas fisik yang dilakukan subjek berkisar antara 5-90 menit dengan dan frekuensi 1-7 kali dalam seminggu. Meskipun terdapat subjek yang melakukan aktivitas fisik berat, namun kegiatan tersebut hanya dilakukan 1-2 kali dalam seminggu terakhir.

Hasil uji chi square menunjukkan perbedaan aktivitas fisik menurut status gizi $p=0,019$ maka dapat disimpulkan terdapat perbedaan aktivitas fisik menurut status gizi pada perokok dewasa awal $(p<0,05)$. Sebanyak $64,9 \%$ subjek non obesitas sentral memiliki aktivitas fisik sedang. Aktivitas fisik dapat menurunkan ukuran lingkar pinggang karena berkaitan dengan penurunan persentase lemak tubuh terutama lemak visceral. ${ }^{31}$ Hasil penelitian ini sejalan dengan hasil penelitian di Finlandia yang menunjukkan bahwa terdapat $68,7 \%$ subjek yang memiliki aktivitas fisik sedang. ${ }^{11}$ Hasil penelitian ini menunjukkan sebagian besar subjek (62,7\%) memiliki aktvitas fisik sedang. Sejalan dengan penelitian di Iran yang menyebutkan bahwa aktivitas fisik pada perokok cenderung lebih ringan dibandingkan dengan non perokok. ${ }^{32}$ Berdasarkan studi, nikotin dan karbon monoksida yang terkandung dalam rokok memiliki dampak terhadap kemampuan kardiorespirasi. Nikotin dapat mengganggu sistem saraf simpatis dengan meningkatkan kebutuhan oksigen, frekuensi denyut jantung, tekanan darah, serta menyebabkan gangguan irama jantung. Karbon monoksida (CO) dapat menurunkan persediaan oksigen untuk jaringan seluruh tubuh termasuk miokard dan dapat pula menimbulkan desaturasi hemoglobin sehingga menurunkan kapasitas latihan fisik. CO menggantikan oksigen di hemoglobin dan mengganggu pelepasan oksigen. ${ }^{33,34}$ Peningkatan $\mathrm{CO}$ dalam hemoglobin mengganggu pengeluaran $\mathrm{O}_{2}$ dalam sel dengan mengurangi jumlah $\mathrm{O}_{2}$ yang dibawa oleh darah melalui pengurangan pada reseptor yang tersedia pada permukaan hemoglobin dan menunda pembongkaran $\mathrm{O}_{2}$ ke dalam otot aktif yang hasilnya adalah penurunan efektivitas mioglobin dalam mengikat $\mathrm{O}_{2}$ pada sel otot. Perokok mengalami penurunan sebesar $10 \%$ dalam durasi latihan fisik yang disebabkan oleh menurunnya produksi $\mathrm{O}_{2}$ dalam jaringan yang dipengaruhi oleh $\mathrm{CO}$ dan juga akibat dari desaturasi $\mathrm{O}_{2}$ dalam saluran darah, dan menurunnya transportasi, suplai dan sistem pengikatan $\mathrm{O}_{2}$ sehingga mengganggu kapasitas latihan fisik. ${ }^{35}$

\section{SIMPULAN}

Sebagian besar perokok dewasa awal memiliki kualitas diet rendah dan aktivitas fisik sedang. Tidak ada perbedaan signifikan kualitas diet menurut status gizi pada perokok dewasa awal. Akan tetapi ada perbedaan signifikan aktivitas fisik menurut status gizi pada perokok dewasa awal.

Kelompok perokok dewasa awal sebaiknya diberikan edukasi dan konseling gizi mengenai kualitas diet yang baik seperti meningkatkan asupan sayur, buah, dan mikronutrien, mengurangi makanan tinggi lemak, serta meningkatkan aktivitas fisik sebagai tindakan preventif terkait masalah kesehatan pada perokok.

\section{DAFTAR PUSTAKA}

1. Kementrian Kesehatan RI. Peraturan Kesehatan Republik Indonesia No. 41 Tahun 2014 Tentang Pedoman Gizi Seimbang. 2014.

2. Departemen Kesehatan. InfoDATIN (Pusat Data Informasi Kementrian Kesehatan RI): Perilaku Merokok Masyarakat Indonesia Berdasarkan Riskesdas 2007 dan 2013. Jakarta: Kementerian Kesehatan; 2013. 2 p.

3. World Health Organization Regional Office for South-East Asia. Global Youth Tobacco Survey (GYTS): Indonesia report, 2014. WHO-SEARO, editor. New Delhi; 2015. 5-16 p.

4. Badan Penelitian dan Pengembangan Kesehatan. Laporan Hasil Riset Kesehatan Dasar (RISKESDAS) Provinsi Jawa Tengah Tahun 2007. Jakarta: Kementerian Kesehatan RI; 2009. 158-160 p.

5. Komiyama $\mathrm{M}$, Wada $\mathrm{H}$, Ura $\mathrm{S}$, Yamakage $\mathrm{H}$, Satoh-asahara N, Shimatsu A, et al. Analysis of Factors That Determine Weight Gain during Smoking Cessation Therapy. PLoS One. 2013;8(8):4-9.

6. Suryadinata R V, Lorensia A, Sari RK. Differences in Nutrition Food Intake and Body Mass Index (BMI) Between Smoker and Non-smoker in Adult. J Farm Klin Indones. 2017;6(3):171-80.

7. Ashkezari MS. Dietary Habits Of Smokers and Non-Smokers, Tehran, Iran : a Case-Control Study. Natl Res Institue Tuberc Lung Dis. 2006;125.

8. Palaniappan U, Starkey LJ, Loughlin JO, Graydonald K. Fruit and Vegetable Consumption Is Lower and Saturated Fat Intake Is Higher among Canadians Reporting Smoking 1. J Nutr. 2001;131(7):1952-8.

9. Paracha PI, Khan T, Vriesekoop F, Salahuddin M. Association between Smoking and Anthropometric Characteristics, Biochemical Markers, and Dietary Intake of Pakistani Male Adult Population. Adv Food Technol Nutr Sci Open J. 2015;1(4):88-96.

10. Papathanasiou G, Papandreou M, Galanos A, Kortianou E, Tsepis E, Kalfakakou V, et al. 
Smoking and Physical Activity Interrelations in Health Science Students. Is Smoking Associated with Physical Inactivity in Young Adults? Hell J Cardiol. 2012;53:17-25.

11. Kujala UM, Kaprio J, Rose RJ. Physical activity in adolescence and smoking in young adulthood: a prospective twin cohort study. Addiction. 2007;102(7):1151-7.

12. Klein S, Allison DB, Heymsfield SB, Kelley DE, Leibel RL, Nonas C. Waist circumference and cardiometabolic risk : a consensus statement from Shaping America's Health: Association for Weight Management and Obesity Prevention; NAASO, The Obesity Society; the American Society for Nutrition; and the American Diabetes. Am J Clin Nutr. 2007;85:1197-202.

13. Shen W, Punyanitya M, Chen J, Gallagher D, Albu $\mathrm{J}$, Pi-sunyer $\mathrm{X}$, et al. Waist Circumference Correlates with Metabolic Syndrome Indicators Better Than Percentage Fat. Obesity. 2006;14(4):728.

14. Badan Penelitian dan Pengembangan Kementerian Kesehatan. Hasil Utama Riskesdas 2018. Kementrian Kesehatan RI; 2018. 69 p.

15. Kee CC, Jamaiyah H, Geeta A, Ali ZA, Safiza MNN, Suzana S, et al. Sensitivity and Specificity of Waist Circumference As A Single Screening Tool for Identification of Overweight and Obesity among Malaysian Adults. Med J Malaysia. 2011;66(5):462-7.

16. Odenigbo UM, Odenigbo UC, Oguejiofor OC. Relationship of Waist Circumference , Waist Hip Ratio and Body Mass Index as Predictors of Obesity in Adult Nigerians. Pakistan J Nutr. 2011;10(1):15-8.

17. Rokhmah FD, Handayani D, Al-rasyid H. Korelasi lingkar pinggang dan rasio lingkar pinggangpanggul terhadap kadar glukosa plasma menggunakan tes toleransi glukosa oral. Indones $\mathbf{J}$ Clin Nutr. 2015;12(1):28-35.

18. Chhabra P, Chhabra S. Effect of Smoking on Body Mass Index: A Community-Based Study. Natl J Community Med. 2011;2(3):325-30.

19. Ginawi IA, Bashir AI, Alreshidi YQ, Dirweesh A, Al-Hazimi AM, Ahmed HG, et al. Association Between Obesity and Cigarette Smoking: A Community-Based Study. J Endocrinol Metab. 2016;6(5):49-152.

20. Kim S, Haines PS, Siega-riz AM, Popkin BM. The Diet Quality Index-International (DQI-I) Provides an Effective Tool for Cross-National Comparison of Diet Quality as Illustrated by China and the United States. J Nutr. 2003;133(11):3476-84.

21. Romaguera D, Rivas A, Feriche B, Pons A, Tur JA. Diet quality of young people in southern Spain evaluated by a Mediterranean adaptation of the Diet Quality Index-International (DQI-I). Br J Nutr. 2008;98:1267-73.
22. Tur JA, Romaguera D, Pons A. The Diet Quality Index-International (DQI-I): is it a useful tool to evaluate the quality of the Mediterranean diet? $\mathrm{Br}$ J Nutr. 2005;93:369-76.

23. Kementerian Kesehatan RI. Pedoman Perkiraan Jumlah Garam dan Penyerapan Minyak Goreng. Jakarta; 2014. 5-6 p.

24. Ainsworth BE, Haskell WL, Whitt MC, Irwin ML, Swartz ANNM, Strath SJ, et al. Compendium of Physical Activities : an update of activity codes and MET intensities. J Am Collage Sport Med. 2014;498-517.

25. Guidelines for Data Processing and Analysis of the International Physical Activity Questionnaire (IPAQ) - Short and Long Forms. 2005.

26. Ahmad N, Ibrahim S, Adam M, Nawi AM. Abdominal Obesity Indicators : Waist Circumference or Waist-to-hip Ratio in Malaysian Adults Population. Int J Prev Med. 2016;7(82).

27. Badan Penelitian dan Pengembangan Kementerian Kesehatan. Riset Kesehatan Dasar. Jakarta; 2013. 223 p.

28. Canoy D, Wareham N, Luben R, Welch A, Bingham S, Day N, et al. Cigarette smoking and fat distribution in 21,828 british men and women: A population-based study. Obes Res. 2005;13(8):1466-75.

29. Octavian Y, Setyanda G, Sulastri D, Lestari Y. Hubungan Merokok dengan Kejadian Hipertensi pada Laki- Laki Usia 35-65 Tahun di Kota Padang. J Kesehat Andalas. 2015;4(2):434-40.

30. McGovern JA, Benowitz N. Cigarette Smoking, Nicotine, and Body Weight. Am Soc Clin Pharmacol Ther. 2011;90(1):164-8.

31. Candrawati S. Hubungan Tingkat Aktivitas Fisik dengan Indeks Massa Tubuh (IMT) dan Lingkar Pinggang Mahasiswa. J Keperawatan Soedirman. 2011;6(2):112-8.

32. Heydari G, Hosseini M, Yousefifard M, Asady H, Baikpour M, Barat A. Smoking and Physical Activity in Healthy Adults: A Cross- Sectional Study in Tehran. Tanaffos. 2015;14(4):238-45.

33. Herawati MH. Bahan yang mengandung zat adiktif pada produk rokok dan dampaknya terhadap kesehatan. In: Kimia dalam Industri dan Lingkungan. Yogyakarta: Prosiding Seminar Nasional XIX; 2017. p. 639-46.

34. Irawati L, Julizar, Irahmah M. Hubungan jumlah dan lamanya merokok dengan viskositas darah. Maj Kedokt Andalas. 2001;35(2):137-46.

35. Papathanasiou G, Mamali A, Papafloratos S, Zerva E. Effects of Smoking on Cardiovascular Function: The Role of Nicotine and Carbon Monoxide. Heal Sci J. 2014;8(2):274-90.

36. Hartono A. Gizi Kesehatan Masyarakat. Gibney MJ, Hartono A, Widyastuti P, Hardiyanti EA, editors. Jakarta: Buku Kedokteran EGC; 2008. 106 p. 